\title{
Cheese whey as potential medium fermentation to Saccharomyces fragilis IZ 275 yeast
}

Soro de queijo como potencial meio de fermentação para levedura Saccharomyces fragilis IZ 275

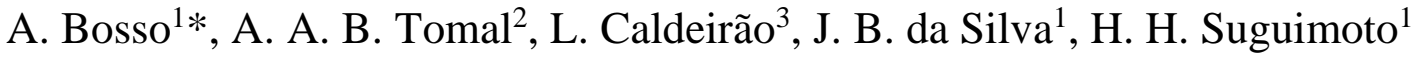 \\ ${ }^{1}$ Universidade Pitágoras Unopar, Departamento de Ciência e Tecnologia de Leite e Derivados, 86.041-140, \\ Londrina, PR, Brazil. \\ ${ }^{2}$ Universidade Estadual de Londrina, Departamento de Ciência e Tecnologia de Alimentos, Campus Universitário, \\ 86.057-970, Londrina, PR, Brazil. \\ ${ }^{3}$ Universidade Estadual de Campinas, UNICAMP, Departamento de Ciência de Alimentos, Cidade Universitária \\ Zeferino Vaz, 13.083-862, Campinas, SP, Brazil. \\ *alessandrabosso@yahoo.com.br
}

(Recebido em 16 de dezembro de 2019; aceito em 17 de fevereiro de 2020)

\begin{abstract}
Yeasts $\beta$-galactosidase is intracellular enzyme, show a high lactose hydrolyzing capacity and therefore can be used to reduce the level of lactose of milk and dairy products. However, the activity of $\beta$-galactosidase, or its production, is strongly influenced by carbon availability as source of energy. The aim of this work was to compare different carbons source with the cheese whey, by-product of dairy industry and potential source to grow microorganism, and its interactions as fermentation mediums to production maximum of $\beta$ galactosidase by Saccharomyces fragilis IZ 275 yeast. The enzymatic activity in the cheese whey and others carbon sources were determined using the o-nitrophenyl- $\beta$-D-galactopyranoside substrate (ONPG). The cheese whey is the better medium fermentation, when compared with others carbon sources, to the production maximum of enzyme. Thus, considered as waste by industry, we prove that the cheese whey opens up another possibility of biotechnological use adding value to the byproduct and meeting the concept of bioeconomy or circular economy.

Key words: carbon source, $\beta$-galactosidase, value added product.
\end{abstract}

A $\beta$-galactosidase de leveduras é uma enzima intracelular, que apresenta alta capacidade de hidrolisar a lactose e, portanto, diminuir o teor de lactose presente no leite e derivados. Contudo, a atividade da $\beta$ galactosidase é influenciada pela disponibilidade de carbono com fonte de energia. O objetivo deste trabalho foi comparar diferentes fontes de carbono com o soro de queijo, um subproduto da indústria de laticínios e fonte potencial de crescimento para microrganismos, e suas interações como meio de fermentação para a máxima produção de $\beta$-galactosidase pela levedura Saccharomyces fragilis IZ 275. A atividade enzimática no soro de queijo e demais fontes de carbono foram determinadas usando o substrato o-nitrofenil- $\beta$-D-galactopiranosideo (ONPG). O soro de queijo é o melhor meio de fermentação, quando comparado com as outras fontes de carbono estudadas, para produção máxima da enzima e assim, pode se tornar uma possibilidade de uso biotecnológico, agregando valor ao subproduto e atendendo ao conceito de bioeconomia ou economia circular.

Palavras-chaves: resíduo, $\beta$-galactosidase, valor agregado.

\section{INTRODUCTION}

Worldwide cheese whey production by dairy industry is estimated at $190 \times 10^{6}$ ton/year [1] being resulted of production of cheese or to remove casein from milk [2] and which cause serious economical and environment problems [3]. The main constituents of cheese whey are lactose (4.5 $-5.0 \% \mathrm{w} / \mathrm{v})$, soluble proteins $(0.6-0.8 \% \mathrm{w} / \mathrm{v})$, lipids $(0.4-0.5 \% \mathrm{w} / \mathrm{v})$ and mineral salts $(8.0-$ $10.0 \% \mathrm{w} / \mathrm{v}$ of dried extract) [4]. Obviously, the lactose disaccharide is the most important component present in the milk and fermented products however, become a serious problem to people with intolerance lactose [5].

$\beta$-galactosidase enzyme (EC 3.2.1.23; $\beta$-D-galactoside galactohydrolase) or commonly known as lactase is an enzyme, responsible to the hydrolysis of $\beta-1,4$-D-galactosidic bonds breaking the lactose, into monosaccharide's, glucose and galactose [6]. The microorganism, including yeasts, 
fungi, bacteria, and actinomycetes, can produce $\beta$-galactosidase enzyme at high levels [7]. Aspergillus ssp. and Kluyveromyces ssp. (species that now includes $K$. fragilis and Saccharomyces fragilis) are widely used on a commercial and industrial scale [8] because are accepted as "generally recognized as safe for human consumption" by Food Drug Administration (FDA). Several factors can influence the production of lactase such as temperature, $\mathrm{pH}$, incubation time and medium fermentation. However, in the medium fermentation is mandatory containing a carbon source to lactase production $[9,10]$.

Traditionally, cheese whey has been used for animal feed and as fertilizer reducing the serious economic and environmental problems as waste. However, the literature shows the possible biotechnological uses of cheese whey $[2,3,10]$. The cheese whey can be used in the hydrolysis of lactose by $\beta$-galactosidase enzyme in its monosaccharide's, glucose and galactose, producing foods with low-lactose or non-lactose that can be consumed by lactose's intolerant individuals.

$\beta$-galactosidase enzyme or lactase is present in a wide of organisms including plants, microorganisms and animal tissue. The main requirement is the amount of carbon source in fermentation media which is the primary energy source and essential for microorganism growth and production of lactase in fermentation [6]. At the present moment, no comparison has been made between various sources of carbon and successive exclusion to show the effect on the $\beta$ galactosidase activity as proposed by the present study.

Therefore, we compared different carbons source with the cheese whey, by-product of dairy industry and potential source to grow microorganism, as fermentation mediums to production maximum of lactase by Saccharomyces fragilis IZ 275 yeast.

\section{MATERIAL AND METHODS}

Saccharomyces fragilis IZ 275 yeast was collected from the Collection of Tropical Cultures (WDCM 885 number), maintained in tubes containing PDA medium (Potato Dextrose Agar) and stored at $4{ }^{\circ} \mathrm{C}$. The cells were reactivated in YM broth $(0.5 \%$ yeast extract and $2 \%$ malt extract and, $\mathrm{pH}$ 5.0) and incubated at $30^{\circ} \mathrm{C}$ for $48 \mathrm{~h}$ in an orbital shaker at $180 \mathrm{rpm}$ (Tecnal, model TE$421)$. The inoculum was standardized by counting cells in a Neubauer chamber $\left(10^{7}\right.$ cells $\left.\mathrm{mL}^{-1}\right)$ and subsequently transferred $(\mathrm{v} / \mathrm{v})$ to the fermentation medium $[10,11]$. The activation medium was pre-autoclaved at $121{ }^{\circ} \mathrm{C}$ for $15 \mathrm{~min}$.

For evaluate the maximum production lactase activity by S. fragilis IZ 275 yeast, we proposed fifteen different fermentation medium (assays) containing sucrose [16.5 $\left.\mathrm{g} \mathrm{L}^{-1}\right]$; powdered cheese whey [17.7 $\left.\mathrm{g} \mathrm{L}^{-1}\right]$ (Cativa, Londrina -PR); glucose $\left[10 \mathrm{~g} \mathrm{~L}^{-1}\right]$; lactose $\left[10 \mathrm{~g} \mathrm{~L}^{-1}\right]$; peptone $\left[8.85 \mathrm{~g}^{-1}\right.$ $\left.\mathrm{L}^{-1}\right]$; yeast extract $\left[5.14 \mathrm{~g} \mathrm{~L}^{-1}\right] ; \mathrm{MgSO}_{4}\left[7 \mathrm{~g} \mathrm{~L}^{-1}\right]$ and $\mathrm{K}_{2} \mathrm{HPO}_{4}\left[5 \mathrm{~g} \mathrm{~L}^{-1}\right]$. According to Table 1 , the sources of carbon (sucrose, cheese whey, lactose and glucose) were evaluated isolated and in combinations, nitrogen sources (peptone and yeast extract) and salts $\left(\mathrm{K}_{2} \mathrm{HPO}_{4}\right.$ and $\left.\mathrm{MgSO}_{4}\right)$ were fixed. The fermentation mediums were autoclaved at $121^{\circ} \mathrm{C}$ for $15 \mathrm{~min}$ prior to addition of the inoculum. All chemicals used in this study were of analytical grade. The experiments were conducted in an orbital rotary incubator (Tecnal, model TE-421, Brazil) with temperature controller and agitation time. The culture mediums were run in $250 \mathrm{~mL}$ Erlenmeyer flasks containing $100 \mathrm{~mL}$ of fermentation medium, incubated on the orbital shaker (Tecnal, TE-420) at $180 \mathrm{rpm}$ at $30{ }^{\circ} \mathrm{C}$ during $72 \mathrm{~h}$. Samples of $80 \mathrm{~mL}$ fermentation medium were centrifuged (Eppendorf centrifuge 5804R, Germany) under conditions of $27,200 \times \mathrm{g}, 4^{\circ} \mathrm{C}$ for $5 \mathrm{~min}$ to the $\beta$ galactosidase enzyme extraction [11]. The supernatant was resuspended in $0.1 \mathrm{M}$ phosphate buffer, $\mathrm{pH}$ 6.6, and centrifuged again under the above conditions. The new precipitate was solubilized in $10 \mathrm{~mL}$ of the same buffer, to which $0.2 \mathrm{~mL}$ of chloroform was added. This mixture was incubated at $37{ }^{\circ} \mathrm{C}$, under agitation of $150 \mathrm{rpm}$ for $17 \mathrm{~h}$. The suspension was then centrifuged and the supernatant used to determine the enzymatic activity. 
Table 1. Medium fermentation to evaluate the maximum production of lactase enzyme.

\begin{tabular}{ll}
\hline \multicolumn{2}{c}{ Assays } \\
1 & Cucrose + cheese whey + glucose + lactose + peptone + yeast extract $+\mathrm{MgSO}_{4}+\mathrm{K}_{2} \mathrm{HPO}_{4}$ \\
2 & Cheese whey + glucose + lactose + peptone + yeast extract $+\mathrm{MgSO}_{4}+\mathrm{K}_{2} \mathrm{HPO}_{4}$ \\
3 & Sucrose + glucose + lactose + peptone + yeast extract $+\mathrm{MgSO}_{4}+\mathrm{K}_{2} \mathrm{HPO}_{4}$ \\
4 & Sucrose + cheese whey + glucose + peptone + yeast extract $+\mathrm{MgSO}_{4}+\mathrm{K}_{2} \mathrm{HPO}_{4}$ \\
5 & Sucrose + cheese whey + lactose + peptone + yeast extract $+\mathrm{MgSO}_{4}+\mathrm{K}_{2} \mathrm{HPO}_{4}$ \\
6 & Cheese whey + glucose + peptone + yeast extract $+\mathrm{MgSO}_{4}+\mathrm{K}_{2} \mathrm{HPO}_{4}$ \\
7 & Cheese whey + lactose + peptone + yeast extract $+\mathrm{MgSO}_{4}+\mathrm{K}_{2} \mathrm{HPO}_{4}$ \\
8 & Glucose + lactose + peptone + yeast extract $+\mathrm{MgSO}_{4}+\mathrm{K}_{2} \mathrm{HPO}_{4}$ \\
9 & Sucrose + cheese whey + peptone + yeast extract $+\mathrm{MgSO}_{4}+\mathrm{K}_{2} \mathrm{HPO}_{4}$ \\
10 & Sucrose + glucose + peptone + yeast extract $+\mathrm{MgSO}_{4}+\mathrm{K}_{2} \mathrm{HPO}_{4}$ \\
11 & Sucrose + lactose + peptone + yeast extract $+\mathrm{MgSO}_{4}+\mathrm{K}_{2} \mathrm{HPO}_{4}$ \\
12 & Sucrose + peptone + yeast extract $+\mathrm{MgSO}_{4}+\mathrm{K}_{2} \mathrm{HPO}_{4}$ \\
13 & Cheese whey + peptone + yeast extract $+\mathrm{MgSO}_{4}+\mathrm{K}_{2} \mathrm{HPO}_{4}$ \\
14 & Lactose + peptone+ yeast extract $+\mathrm{MgSO}_{4}+\mathrm{K}_{2} \mathrm{HPO}_{4}$ \\
15 & Glucose + peptone + yeast extract $+\mathrm{MgSO}_{4}+\mathrm{K}_{2} \mathrm{HPO}_{4}$ \\
\hline
\end{tabular}

The enzymatic activity in the cheese whey was determined using the o-nitrophenyl- $\beta$-Dgalactopyranoside substrate (ONPG). The ONPG $(1.25 \mathrm{mM})$ substrate dissolved in $0.05 \mathrm{M}$ sodium phosphate buffer ( $\mathrm{pH}$ 7.0) was used. The amount of substrate and enzyme used were 2 $\mathrm{mL}$ and $0.5 \mathrm{~mL}$, respectively. At the time zero, $0.5 \mathrm{~mL}$ of enzyme solution was added to the ONPG solution and incubated for $15 \mathrm{~min}$. The assay was stopped by the addition of $0.5 \mathrm{~mL} 1 \mathrm{M}$ sodium carbonate, and the absorbance was determined in spectrophotometer (Biochrom libra S22 Cambridge England) at $420 \mathrm{~nm}$. One enzymatic unit was defined as the quantity of enzyme that would liberate $1 \mathrm{mM}$ of onitrophenol from ONPG per minute under the assay conditions. Enzymatic units were calculated using the following equation (1):

Unit $\mathrm{mL}^{-1}=\mathrm{A} \times$ dilution factor/ $/ \varepsilon$ time $\mathrm{x}$ enzyme solution

(Equation 1)

where A was the absorbance at $420 \mathrm{~nm}$, dilution factor was the fold dilution of the enzyme solution, enzyme solution was the amount of enzyme $(\mathrm{mL})$ undergoing the reaction, $\varepsilon$ was the extinction coefficient (determined from the O-nitrophenol standard curve) and time was the incubation time (5 min).

The data were submitted to analysis of variance (ANOVA) and the means were compared by Tukey's test, at $5 \%$ probability using the STATISTICA 7.0 software (StatSoft Inc., 2007).

\section{RESULTS AND DISCUSSION}

According to Figure 1, the highest $\beta$-galactosidase activity value by Saccharomyces fragilis IZ 275 yeast was observed in the assay $1\left(54.57 \mathrm{U} \mathrm{mL}^{-1}\right)$ which the fermentation medium contained all carbon source followed by assay $5\left(36.35 \mathrm{U} \mathrm{mL}^{-1}\right)$ which glucose was excluded as a source of carbohydrate. When was excluded the cheese whey (assay 8) the activity enzymatic decreased to $20.08 \mathrm{U} \mathrm{mL}^{-1}$. The lower $\beta$-galactosidase activity values were obtained in the assay $15\left(4.60 \mathrm{U} \mathrm{mL}^{-1}\right)$ but not differ of assay $11\left(5.08 \mathrm{U} \mathrm{mL}^{-1}\right)$ and $12\left(4.95 \mathrm{U} \mathrm{mL}^{-1}\right)$. The results suggested that sucrose, lactose and glucose as only carbohydrate source were not efficient to high produce $\beta$-galactosidase enzyme by Saccharomyces fragilis IZ 275 yeast when compared with the assay 13 which contain only cheese whey as carbon source in fermentation medium. Therefore, if the economically viable choice is for only one source of carbon, the cheese whey is the better for the maximum activity enzyme since it presented approximately twice the activity value when compared to lactose and three times more activity than glucose and sucrose. 


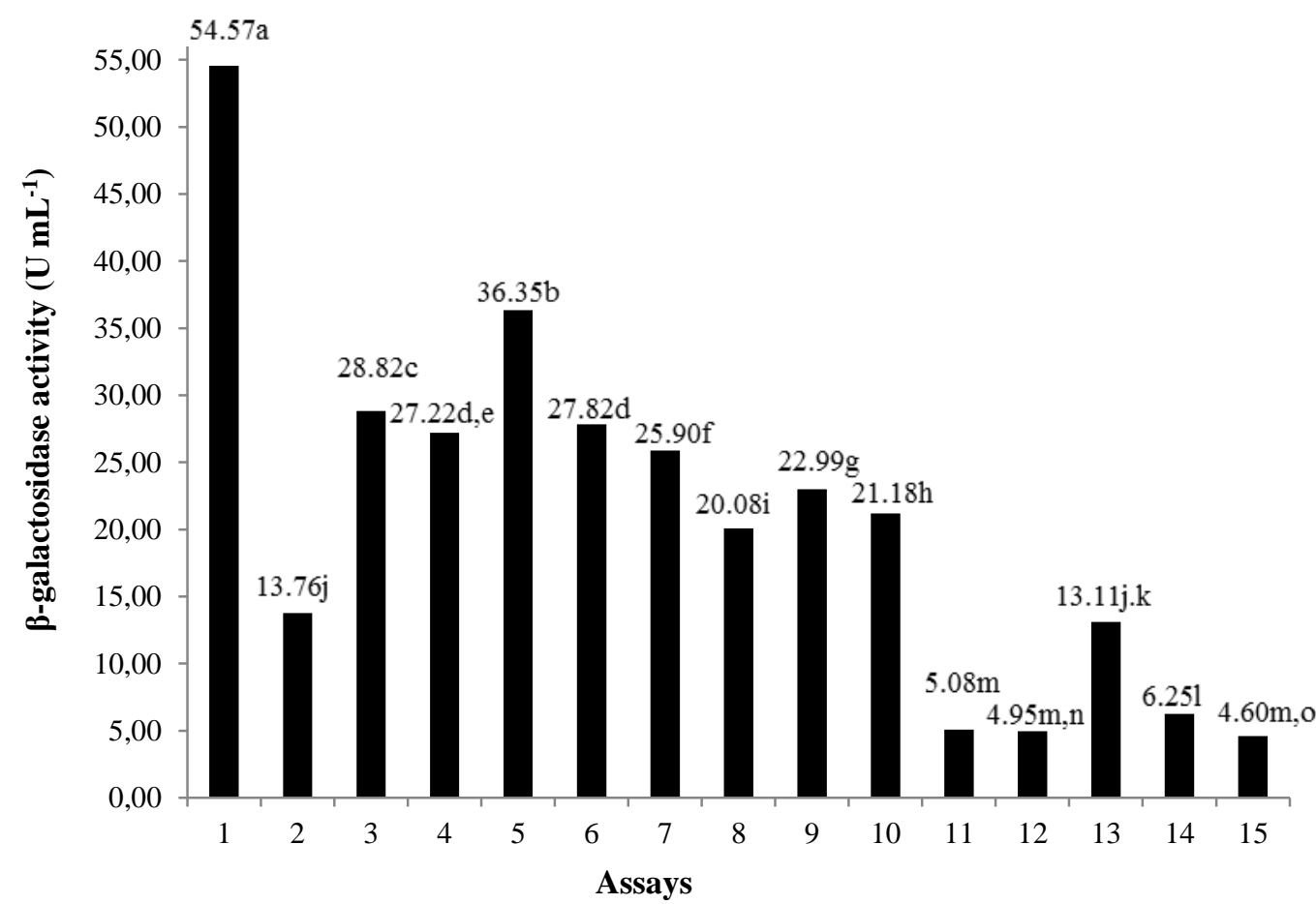

Figure 1. $\beta$-galactosidase activity $\left(U m L^{-1}\right)$ of different assays. Means followed by equal letters, in the columns, do not differ by Tukey's test, at 5\% probability. The assays from 1 to 15 are corresponding to Table 1.

\section{CONCLUSION}

Cheese whey, when used as only carbon source, is the best to production of $\beta$-galactosidase by Saccharomyces fragilis IZ 275 yeast compared with sucrose, lactose and glucose.

\section{REFERENCES}

1. El-Tanboly E, Mahmoud E, Khorshid. Recovery of cheese whey, a by-product from the dairy industry for use as an animal feed. J Nutri Health Food Eng. 2017;6(5):148-154, doi:10.15406/jnhfe.2017.06.00215.

2. Ryan MP, Walsh G. The biotechnological potential of whey. Rev Environ Sci Biotechnol. 2016;15:479498, doi:10.1007/s11157-016-9402-1.0

3. Mollea C, Marmo L, Bosco F. Valorisation of Cheese Whey, a By-Product from the Dairy Industry. In: Muzzalupo I (ed) Food Industry. InTech. 2013, doi:10.5772/53159.

4. Kosseva MR, Panesar PS, Kaur G, Kennedy JF. Use of immobilized biocatalyts in the processing of cheese whey. Int J Biol Macromolecules. 2009;45:437-47, doi:10.1016/j.ijbiomac.2009.09.005

5. Silva PHF, Oliveira VCD, Perin LM. Cow's Milk Protein Allergy and Lactose Intolerance. In: Raw Milk, Academic Press. 2019. Pp.: 295-309, doi:10.1016/B978-0-12-810530-6.00014-6.

6. Anisha GS. $\beta$-galactosidases. In: Current Developments in Biotechnology and Bioengineering. 2017; Pp.: 395-421.

7. Saqib S, Akram A, Halim AS, Tassaduq R. Sources of b-galactosidase and its applications in food industry. 3Biotech. 2017;7(1):79, doi:10.1007/s13205-017-0645-5.

8. Hussain Q. Beta-galactosidases and their potential applications: a review. Critical Rev Biotechnol 2010;30:41-62, doi:10.3109/07388550903330497.

9. Viana CS, Pedrinho DR, Morioka LRI, Suguimoto HH. Determination of cell permeabilization and beta-galactosidase extraction from Aspergillus oryzae CCT 0977 grown in whey cheese. Int J Chem Eng. 2019;6, doi:10.1155/2018/1367434.

10. Macwan SR, Bhumika KD, Parmar SC, Aparnathi KD. Whey and its Utilization. Int J Current Microbiol Appl Sci. 2016;8:134-155, doi:10.20546/ijcmas.2016.508.016.

11. Prasad LN, Ghosh C, Sherkak F, Shah NP. Extraction and characterisation of $\beta$-galactosidase produced by Bifidobacterium animalis spp. lactis Bb12 and Lactobacillus delbrueckii spp. bulgaricus ATCC 11842 grown in whey. Int Food Res J. 2013;20:487-494. 